Research Article

\title{
The evaluation of collaborative synchronous learning environment within the framework of interaction and community of inquiry: An experimental study
}

\author{
Alper Aslan \\ Munzur University, Turkey
}

\begin{abstract}
This study aims to investigate a collaborative synchronous learning environment in terms of students' community of inquiry perceptions (cognitive, social, and teaching presences) and interaction levels. This quantitative study was conducted with the participation of fifty-nine freshmen (twenty-nine in the control group and thirty in the experimental group) in the department of Information Technologies at a university. The study lasted nine weeks, including two weeks of data collection and seven weeks of implementation procedure. After the implementation, the Community of Inquiry Scale and the Online Course Interaction Level Determination Scale were administered to the participants. The results revealed that co-operative synchronous learning experiences positively influenced students' community of inquiry perceptions and interaction levels in the experimental group. Further results and implications are discussed at the end.
\end{abstract}

Keywords: Collaborative learning; Community of inquiry; Interaction; Synchronous online course

Article History: Submitted 13 January 2020; Revised 11 April 2021; Published online 17 May 2021

\section{Introduction}

Online learning environments are often used in addition to face-to-face learning environments (Al Mamun et al., 2020) in order to help students to achieve required skills (Tareef, 2014). Specifically, online learning environments emerged as the best alternative to on-site education to meet students' educational needs during the COVID-19 pandemic process (Ishak et al., 2020; Sun et al., 2020). Considering its major role in the continuation of educational activities during the pandemic, there is a need to conduct research in order to increase its effectiveness. Recently conducted studies could be considered as a reflection of this need (Adarkwah, 2021; Aguilera-Hermida, 2020; Almaiah et al., 2020; Burke \& Dempsey, 2020; Butler-Henderson \& Crawford, 2020; Deshmukh, 2020; Shire et al., 2020). As Cheng and Chau (2016) suggest, one of the limitations that negatively affect the quality of online education is interaction problem.

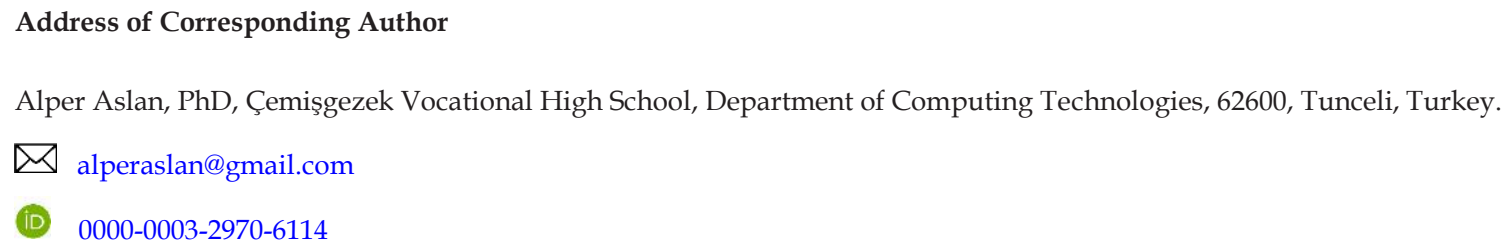

How to cite: Aslan, A. (2021). The evaluation of collaborative synchronous learning environment within the framework of interaction and community of inquiry: An experimental study. Journal of Pedagogical Research, 5(2), 72-87. http://dx.doi.org/10.33902/JPR.2021269326 
Interaction is considered as a major limitation for online learning environments (Anderson, 2003). Cheng and Chau (2016) consider it as a factor that facilitates the learning process and increases students' performance in this process. Related studies reveal that the level of interaction significantly affects the success of online learning environments (Hawkins et al., 2013; Ji, Park, Jo, \& Lim, 2016). Studies reporting that the interaction level was not at the desired level in online learning environments (Al-Musharraf \& Alkhattabi, 2016; Turgut \& Karal, 2015; Zhang et al., 2018) imply the necessity of more research to determine how to improve it in those environments (Owusu-Agyeman \& Larbi-Siaw, 2018). In addition, it is thought that interaction problems will affect the online learning process more, especially in emergency remote education, which students and teachers across the world have shifted to. One of the underlying reasons is that students and teachers have had little or no experience and/or knowledge regarding online learning until they are forced to become a part of it due to the pandemic. According to a UNESCO report (2020), this problem was not an unexpected situation considering that around $92 \%$ of students all over the world shifted to emergency remote education urgently.

Effective use of technology in online learning environments may result in more interaction between teachers and students, as well as in more collaboration among students (Bower, 2019; Gonzalez et al., 2020; Ku et al., 2013; Petronzi \& Petronzi, 2020). Blasco-Arcas et al. (2013) report a positive association between students' interaction and active learning, which also results in higher learning performance. An increase in interaction between teachers and students results in an increase in students' perceptions towards learning (Paswan \& Young, 2002) and satisfaction (Lee, Srinivasan et al., 2011). Within this context, through the use of pedagogical approaches, with the support of the adaptable communication and interaction capacity of online environments (Anderson, 2008), improvements can be achieved in many dimensions affecting the success of online learning, such as academic achievement, perceived learning, and satisfaction. However, when adopting a pedagogical approach in online learning environments, computer and communication technologies should be considered as tools in applying the approach and instructional design (Arenas, 2015). However, optimum benefit can be achieved by determining the most appropriate approach suitable for using these tools. Today, many synchronous online learning platforms have effective features to share audio, video, file, and the whiteboard. Those platforms are updated regularly in order to keep up with the needs of users. One critical update is the breakout room that enables teachers to create small groups for discussions. In each breakout room, students can share video, audio, file, and screen in order to work collaboratively. Through interaction, these breakout rooms may be an effective tool for teachers to employ a collaborative learning approach. With collaboration, students can interact with other students in order to solve problems they cannot solve individually (Grau \& Whitebread, 2012) and to develop higher-order thinking skills (Oliveira et al., 2011). Collaboration is widely-used in both face-to-face and online learning environments as it enables students to work in small groups and to construct knowledge together (Fischer et al., 2007; Liu \& Tsai, 2008).

Studies generally examine the effectiveness of online learning in terms of academic performance (Lee \& Lee, 2008), students' satisfaction (Heo \& Han, 2003; Ozkan \& Koseler, 2009), perceived learning (Eom \& Ashill, 2016), and so on. Specifically, Garrison et al. (2001) provide a community of inquiry model, a methodological guide to design, ease, and evaluate the effectiveness of the online learning process. In the model, its effectiveness is evaluated based on students' cognitive, social, and teaching presence perceptions. The community of inquiry model is being used to evaluate the online learning environments, which have been rapidly spreading all over the world. Researchers from different countries report its effectiveness in predicting students' experiences in online environments and their satisfaction levels (Joo et al., 2011; Lee et al., 2020; Maddrell et al., 2017; Mills et al., 2016).

Recent studies examined emergency remote education, which has been in practice due to the pandemic, to find solutions to the problems encountered. Specifically, such studies generally focused on the evaluation of emergency remote education (Al Lily et al., 2020), students' and 
teachers' adaptation problems (Mishra et al., 2020), students' perceptions concerning video-based learning (Pal \& Patra, 2020), their affective needs (Kaplan-Rakowski, 2020), and their scientific selfefficacy and cognitive anxiety (Yang et al., 2020). Our study focuses on the perceptions of interaction and community of inquiry in distance education given that these are the issues that have not been examined in detail yet. Interaction is accepted as an important limitation in distance education (Anderson, 2003; Cheng \& Chau, 2016) and significantly affects the success of online learning environments (Ji et al., 2016). Besides, Owusu-Agyeman and Larbi-Siaw (2018) indicate that there is a need for studies to increase the level of interaction in online learning environments. The study examines collaborative synchronous learning environment (CSLE) within the community of inquiry framework. Thus, the effects of CSLE on students' social, cognitive and instructional levels were investigated. Considering that using the perceptions of the community of inquiry is an effective approach in predicting the success of the online learning environment and student satisfaction (Lee et al., 2020; Maddrell et al., 2017), it is thought that the obtained research results will contribute to the literature. Thus, the aim of the study is to examine collaborative synchronous learning environment within the framework of interaction and community of inquiry. The following research questions are addressed:

- Is there a significant difference between the experimental and control groups in terms of the community of inquiry model features, including cognitive, social, and teaching presence?

- Is there a significant difference between the experimental and control groups in terms of interaction levels?

\subsection{Literature Review}

\subsubsection{Collaborative learning}

Collaborative learning is an effective method that enables students to work in small groups in order to achieve a common goal (Liu \& Tsai, 2008; Prince, 2004). In comparison to individual learning, collaborative learning supports students' comprehension skills, their participation in the learning process, creative problem-solving skills, socialization, and language development (Tomcho \& Foels, 2012). The formation of groups is a critical process in effective collaborative learning environment (Chan et al., 2010). The number of group members and the interaction among them are critical factors that directly influence the effectiveness of collaborative learning (Chen \& Kuo, 2019). Specifically, Moreno et al. (2012) state that having effective groups in collaborative learning provides a high level of interaction between group members and is important to achieve desired learning outcomes. There are three frequently-used methods in group formation; random grouping, determination of group members by teachers, and determination of group members by students (Chan et al., 2010; Hilton \& Phillips, 2010; Huxham \& Land, 2000). Homogeneity between groups and heterogeneity within groups are expected in group formation (Moreno et al., 2012; Scheurell, 2010). On the other hand, certain disadvantages of collaborative learning exist regarding group work. For example, Alfonseca and her colleagues (2006) state that placing strong emphasis on group formation might negatively affect learning. Although heterogeneity among individuals is desired within groups, this may also cause cognitive, motivational, and emotional conflict among group members (Järvelä \& Järvenoja, 2011; Järvelä et al., 2008).

Due to technological developments, various synchronous and asynchronous tools are used in online learning environments. Since they enable group-work and support cooperation, coordination, and interaction (Ornellas \& Muñoz Carril, 2014), they are preferred in collaborative learning environments. However, along with these tools, effective guidance and support is required for the success of the learning process (Kopp et al., 2012). Additionally, Remond and Lock (2006) discuss seven components of online collaborative learning (see Figure 1). 
Figure 1

Online collaborative learning framework (Redmond \& Lock, 2006)

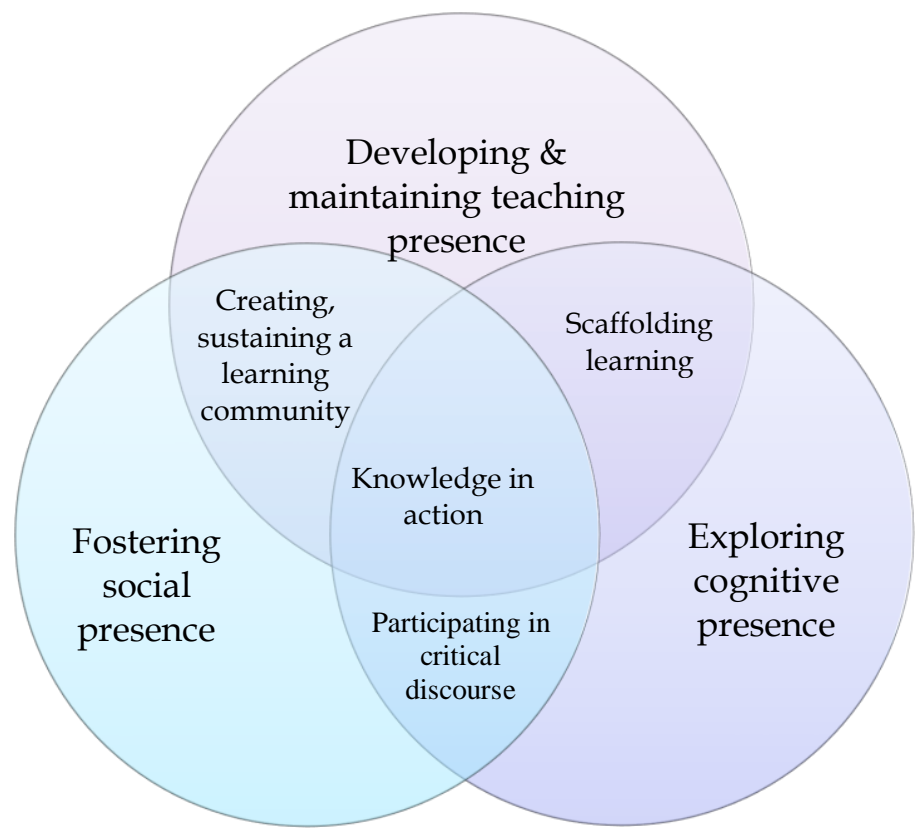

As can be seen in the figure, each component in the framework includes an action. These components aim to provide effective learning experiences by guiding the learning process in collaborative online learning environments. Redmond and Lock (2006) explain these components as follows:

- Fostering social presence: Feeling connected to or realistic in online discussion

- Developing and maintaining teaching presence: Designing and implementing teaching strategies for learning experiences

- Exploring cognitive presence: Designing and implementing activities and strategies for critical thinking

- Creating and sustaining a learning community: Learning how to communicate and collaborate in order to support learning

- Scaffolding learning: Designing activities to encourage deep learning

- Participating in critical discourse: Integration of different perspectives on prior knowledge to generate new knowledge

- Knowledge in action: Creating, problem-solving and acting

\subsubsection{Interaction in online learning environments}

As in face-to-face education, interaction is a critical factor affecting learning (Anderson, 2003; Lou et al., 2006). Through a meta-analysis conducted by Bernard and his colleagues (2009) of seventyfour empirical studies, a positive effect of interaction on learning was reported. In 1989, Moore labeled three types of interaction as learner-learner, learner-instructor, and learner-content interactions. Since then, new interaction types (e.g., instructor-content interaction) were added to Moore's categorization (Anderson \& Garrison, 1998; Hillman et al., 1994) but we will only use the original three-partite categorization. The first one of them, learner-learner interaction, refers to the interaction among students working individually or in small groups (Moore, 1989). In particular, audio and video communication tools that are integrated into the online learning environments increase learner-learner interaction. The second one, learner-instructor interaction is also accepted to be critical in order to maintain students' interest towards courses at a high level, to motivate them, and to keep them active in the learning process. In online learning environments, many 
synchronous and asynchronous tools are used to enable learner-instructor interaction. The last interaction type in Moore's categorization is learner-content interaction, which refers to students' interaction with content that causes changes in the students' cognitive structures or perspectives (Moore, 1989). Each interaction type complements each other. Therefore, for more effective online learning, all types of interaction must occur at a certain level (Ji et al., 2016; Hawkins et al., 2013).

\subsubsection{Community of inquiry}

The community of inquiry framework provides an integrated perspective of constructivist approaches in terms of learning and the mediation of technologies (Garrison et al., 2001). In the community of inquiry model, the quality of educational experience depends on cognitive, social, and teaching presence, and each of these presence types represents only one dimension of educational experience (Szeto, 2015). Although studies reveal that three presence entities do not have an equal role in the learning process (Akyol \& Garrison, 2011; Kozan \& Richardson, 2014), Garrison (2011) state that all three are required for learning. Garrison and his colleagues (1999) consider these entities to be interconnected to each other, as shown in Figure 2 below.

Figure 2

Community of inquiry model (Garrison et al., 1999)

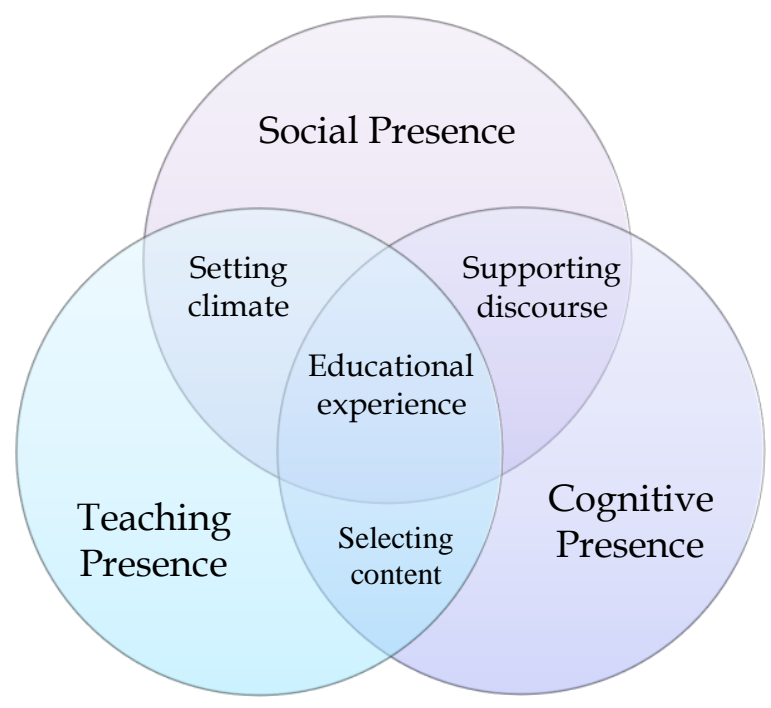

As Figure 2 represents, community of inquiry has three entities connected to each other in an online learning environment. Garrison and his colleagues (1999) describe these entities as follows:

- Social presence: students' ability to represent themselves as real people in an online community.

- Cognitive presence: the conceptualization of a problem, the communication with others to discover knowledge about the problem, the construction of meaning from acquired information, and the solution of the problem with a consensus.

- Teaching presence: the design, facilitation, and orientation of cognitive and social assets in order to achieve meaningful and useful learning outcomes.

\section{Method}

In this study, a quasi-experimental research design is employed in order to determine students' perceptions towards the community of inquiry in terms of cognitive, social, and teaching presence as well as their interaction levels. 


\subsection{Participants and Context}

The participants of the study consisted of fifth-nine freshmen from two classrooms at a university located in the eastern part of Turkey. All students registered a course entitled Information Technologies, which is a mandatory course for freshmen. The study lasted for nine weeks, from October to December, 2020. The data was collected during the first and last weeks of the study. McMillan and Schumacher (2010) state that the experimental and control groups have to have similar characteristics if they are not identified randomly. In the study, the two questionnaires were not administered at the beginning of the study, since the items in the questionnaires concerned activities conducted in online courses. An example item is, 'Learning activities helped me to write down explanations and solutions'. Therefore, in order to determine whether the groups had similar characteristics, different variables were considered. First, since the participants were freshman from two different classrooms in the same major, their university entrance exam scores were similar. Second, certain demographic information regarding the participants was compared with the results revealing that the students in both groups had similar characteristics. Table 1 provides demographic information about the participants.

Table 1

Demographic information about the participants

\begin{tabular}{|c|c|c|c|}
\hline & & Classroom A & Classroom B \\
\hline \multirow[t]{3}{*}{ Age } & 18-19 & 20 & 16 \\
\hline & $20-21$ & 9 & 10 \\
\hline & $21+$ & - & 4 \\
\hline \multirow{2}{*}{$\begin{array}{l}\text { Experience in computer use for } \\
\text { educational purposes }\end{array}$} & $1-2$ year & 22 & 24 \\
\hline & 3-4 year & 7 & 6 \\
\hline \multirow[t]{2}{*}{ Experience in distance education } & Yes & 8 & 10 \\
\hline & No & 21 & 20 \\
\hline \multirow{2}{*}{$\begin{array}{l}\text { Experience in synchronous } \\
\text { online courses }\end{array}$} & Yes & 11 & 10 \\
\hline & No & 18 & 20 \\
\hline
\end{tabular}

Third, at the beginning of the study, the interaction anxiousness levels and communication skills of the students were examined. The rationale for this examination is that since the study focuses on the interaction and community of inquiry perceptions (cognitive, social, and teaching presence) in collaborative online learning environments, the similarity of the groups is considered to be important in terms of these two variables. As the data was normally distributed, an independent samples t-test was conducted to examine the interaction anxiousness levels and communication skills of the groups. The results are provided in Table 2.

Table 2

Independent samples t-test results for the interaction anxiousness scores and communication skills scores

\begin{tabular}{|c|c|c|c|c|c|c|c|}
\hline Dependent Variable & Groups & $N$ & Mean & $S D$ & $d f$ & $t$ & $p$ \\
\hline \multirow{2}{*}{$\begin{array}{l}\text { Interaction } \\
\text { Anxiousness }\end{array}$} & Classroom A & 29 & 41.36 & 11.43 & \multirow[t]{2}{*}{57} & \multirow[t]{2}{*}{-1.080} & \multirow[t]{2}{*}{.285} \\
\hline & Classroom B & 30 & 44.68 & 12.20 & & & \\
\hline \multirow[t]{2}{*}{ Communication Skills } & Classroom A & 29 & 105.73 & 9.87 & \multirow[t]{2}{*}{57} & \multirow[t]{2}{*}{1.176} & \multirow[t]{2}{*}{.244} \\
\hline & Classroom B & 30 & 102.68 & 10.01 & & & \\
\hline
\end{tabular}

According to the results, no significant difference was observed between students in Classrooms A and $\mathrm{B}$ in terms of interaction anxiousness $(t(57)=1.146 ; p>.05)$ and communication skills $(t(57)=-1.176 ; p>.05)$ scores. These results imply that the students in both classrooms had similar characteristics. Therefore, while Classroom A was assigned as the control group, Classroom B was assigned as the experimental group randomly. 
For this particular study, a course entitled 'Information Technologies' was chosen. In order to design activities for the experimental group, seven objectives were determined. A list of the objectives is given in Table 3 .

Table 3

Identified Objectives

\begin{tabular}{cl}
\hline Objective No & Objective \\
\hline 1 & Knows the basic concepts related to computer systems and the operating system. \\
\hline 2 & Knows the functions of computer hardware components. \\
\hline 3 & Knows Windows operating system and configures setup settings. \\
\hline 5 & Knows the Internet and how to search for information via the Internet. \\
\hline 6 & $\begin{array}{l}\text { Creates text files, writes formulas, and creates tables using the MS Word } \\
\text { application and makes changes in the program and document properties. }\end{array}$ \\
\hline 7 & $\begin{array}{l}\text { Creates workbooks and cell formulas, adds formulas using the MS Excel } \\
\text { application and makes changes in the program and Workbook properties. } \\
\text { uses features, such as adding animations and designs, and makes changes in the } \\
\text { program and presentation properties. }\end{array}$ \\
\hline
\end{tabular}

\subsection{Data Collection Tools}

\subsubsection{Demographic information form}

A demographic information form was developed by the researchers in order to obtain the participants' demographic information. The participants were asked to report their age and experience in computer use for educational purposes, distance education, and the synchronous online course. The form was completed at the beginning of the implementation by all of the participants.

\subsubsection{Interaction anxiousness scale}

The scale, developed by Coşkun (2009), is a five-point Likert type. It consists of fifteen items with one factor. There were five reversed-coded items. The Cronbach's alpha value was calculated as .91. A minimum of 15 and a maximum of 75 scores can be obtained from the scale. The obtained results are interpreted as the higher the score obtained from the scale is, the higher the interaction anxiousness level is.

\subsubsection{Communication skills scale}

In order to measure the participants' communication skills, a questionnaire developed by Korkut Owen and Bugay (2014) was used. The scale is a five-point Likert type with twenty-five items. It has four factors; communication principles and basic skills, self-expression, effective listening and non-verbal communication, and willingness to communicate. The Cronbach's alpha values for the whole scale and its factors were calculated as .79, .72 .64, .71, and .88, respectively. The scores of 25 125 are obtained from the scale, and getting a high score indicates that stronger communication skills are.

\subsubsection{Online course interaction level determination scale}

In order to examine the participants' online course interaction levels, a questionnaire developed by Karaman (2015) was used. The five-point Likert type scale consists of twenty-five items with four factors; student, instructor, content, and presentation type. The Cronbach's alpha values for the whole scale and its factors were calculated as .89, .92, .68, .66, .46, and .89, respectively. A minimum of 14 and a maximum of 70 scores in four dimensions can be obtained from the scale. It is interpreted as the higher the score obtained from the scale is, the higher the rate of live online class interaction is. 


\subsubsection{Community of inquiry scale}

In order to evaluate the online learning environment at the end of the implementation, the community of inquiry scale was used. The scale was developed by Arbaugh and his colleagues (2008) and translated into Turkish by Öztürk (2012). The four-point Likert type scale consists of thirty-four items with three factors; teaching presence (item 1 to 13), social presence (item 14-22), and cognitive presence (item 23-34). The Cronbach's alpha values for the whole scale and its factors were calculated as $.97, .92, .88$, and .75 , respectively. The scores of 34-136 from 34 items are obtained from the scale. As well as each dimension is evaluated within itself, evaluation can also be carried out on the total score.

\subsection{Implementation Procedure}

The activities were held in synchronous online settings for both the control and experimental groups. While activities related to the objectives were designed based on a collaborative learning approach for the experimental group, no intervention was adopted in the control group. The Zoom application with its audio, video, content share, and other features was used in both groups. The implementation took nine weeks in total; two weeks for the data collection and seven weeks for the implementation. The implementation process is shown in Figure 3.

Figure 3

Experimental procedure

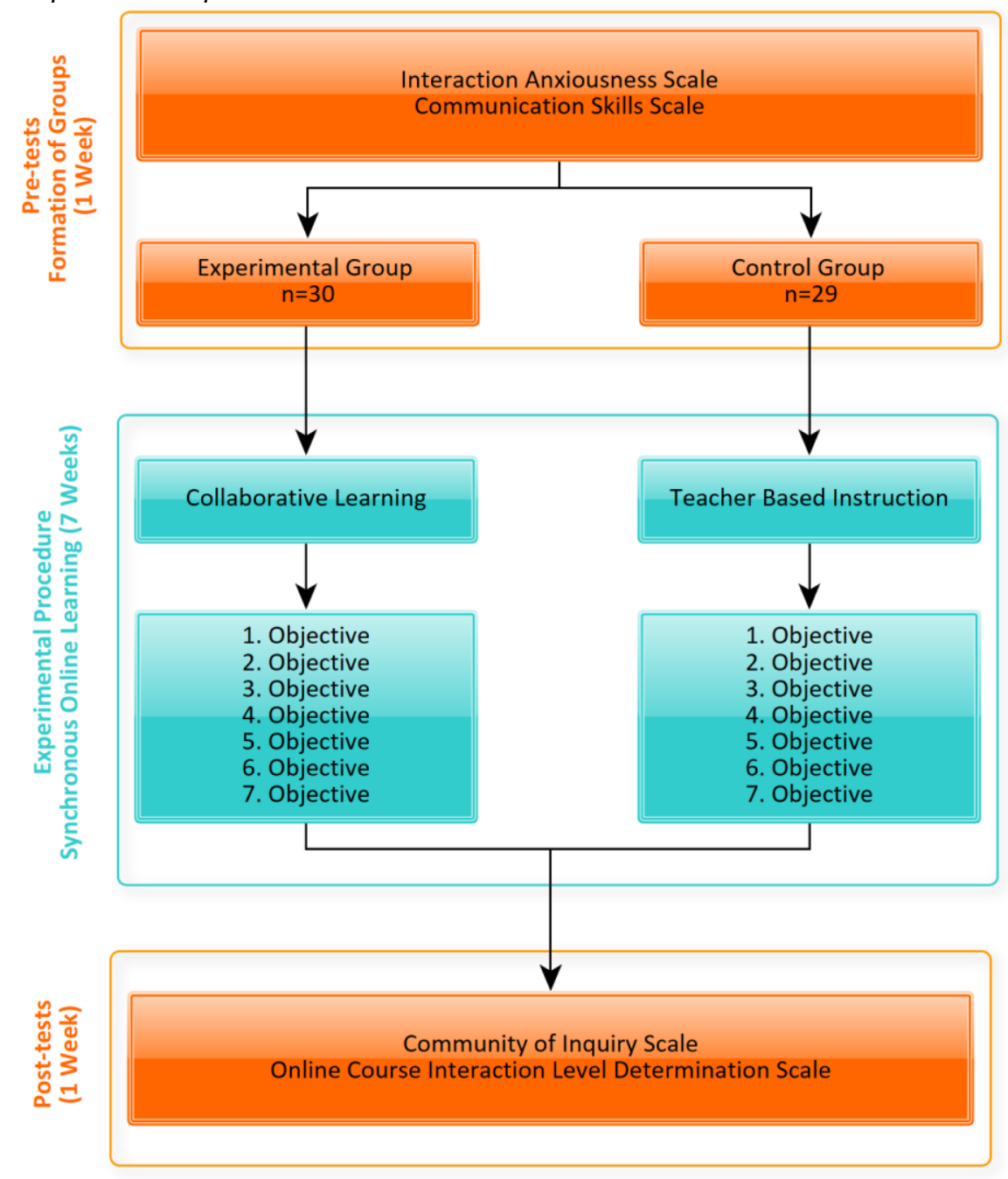

As can be seen in Figure 3, the interaction anxiousness scale and the communication skills scale were administered in the first week of the study in order to determine whether the groups had similar characteristics. After ensuring similarity in characteristics, the groups were randomly 
assigned as the control and the experimental. Before the implementation process, the aim of the course and the objectives were introduced to the students in both groups. In collaborative learning environments, students work in groups in order to complete a task (Prince, 2004). For effective collaboration, formation of groups (Chan et al., 2010) and communication within groups (Chen \& Kuo, 2019) are critical. Therefore, both the formation of the groups at the beginning of the implementation and interaction throughout the implementation were given additional attention in the study. During the formation of the groups, homogeneity between groups and heterogeneity within the groups were ensured as Moreno and her colleagues suggest (2012). The gender, experience in using computers, communication skills, and communication anxiousnes levels of the students were taken into account during the formation of the groups. As a result, six groups of five students were formed. Each group was asked to identify a leader among their group members.

During the implementation, three lessons were designed for each week for both groups with each lesson taking approximately thirty minutes. For the experimental group, the instructor introduced the related objective in the first lesson of each week. At the beginning of the second lesson, students were informed about the activity and then the group members met in the Zoom breakout rooms. During the second lesson, the instructor visited each breakout room and provided guidance to the groups if needed. In particular, the instructor made sure that the discussions concerned the objective of the week and that the group members were active while completing the activities. Each group shared their products with the other groups in the third lesson and all of the students discussed the products. The instructor's role in the third lesson was to guide the students in their discussions. The same procedure was followed during the rest of the weeks. An example scene from a lesson designed for the experimental group is given in Figure 4. There was no intervention program administered to the control group and the instructor used two teaching methods; direct instruction and questioning.

Figure 4

An example scene from an online lesson of the experimental group

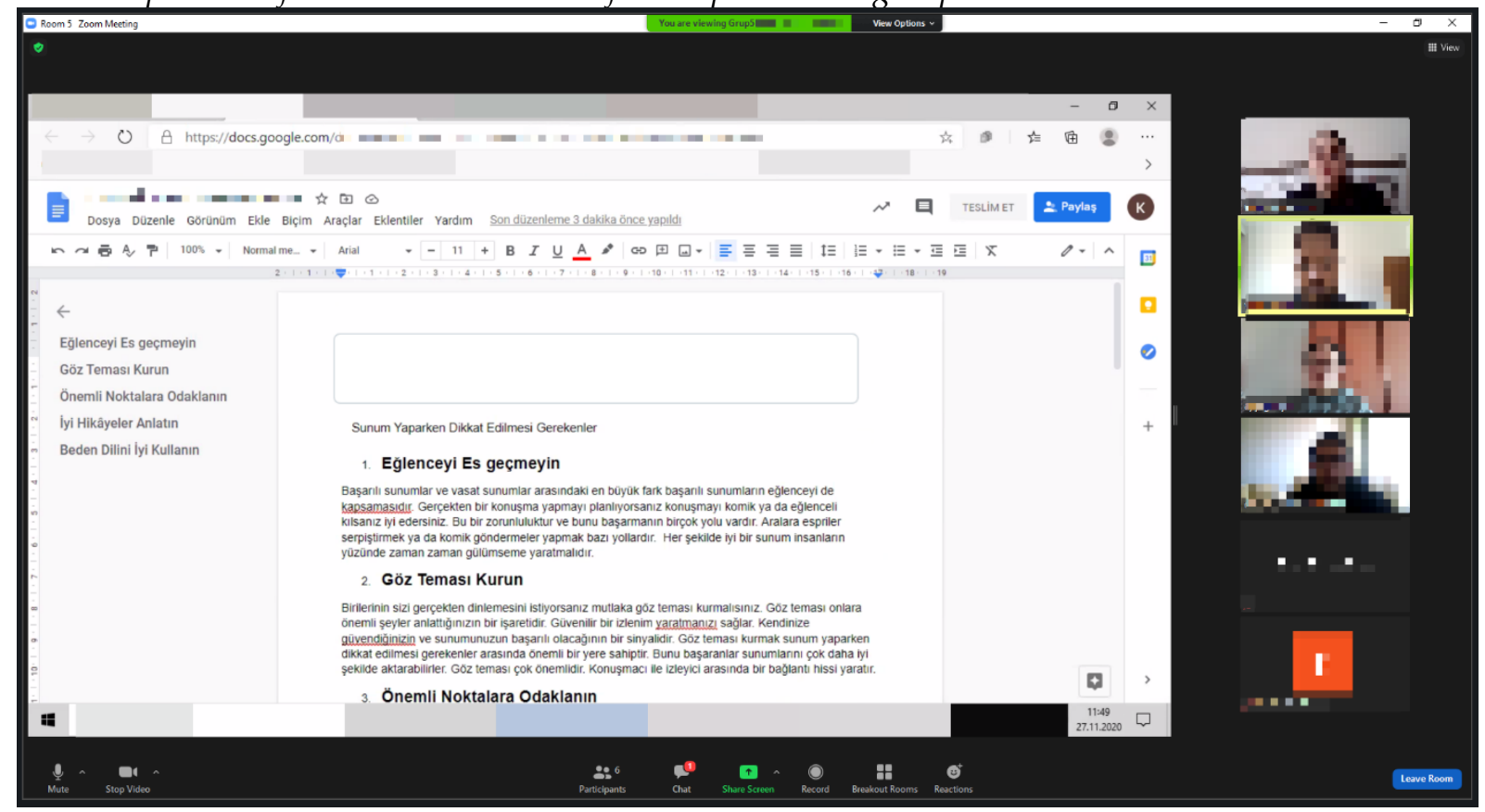

\subsection{Data Analysis}

In this study, descriptive and inferential statistics were employed in analyzing the data. The data was examined to determine whether it was normally distributed by conducting the Shapiro-Wilk Test. Since the data was normally distributed, an independent samples t-test was performed. In statistical analysis, the significance level was set at .05. When a significant difference was observed 
between the groups, effect size ( 12$)$ was calculated. Eta-square effect size enables researchers to determine the magnitude of the association (Pallant, 2016). The effect size is considered as small, medium, and large if $\eta 2<.01,<.06$, and <.14, respectively (Cohen, 1992).

\section{Results}

The results of this study examining collaborative synchronous learning environments (CSLE) in terms of community of inquiry and interaction are presented within the framework of the research questions.

\subsection{Community of Inquiry Perceptions}

Based on the first research question, the difference between the experimental and control groups in terms of community of inquiry perceptions were investigated. The independent samples t-test results are provided in Table 4.

Table 4

Independent samples t-test results for community of inquiry perception scores

\begin{tabular}{|c|c|c|c|c|c|c|c|}
\hline Groups & $N$ & Mean & $S D$ & $d f$ & $t$ & $p$ & $\eta 2$ \\
\hline Experimental & 30 & 117.03 & 11.73 & 57 & 2.419 & .019 & .093 \\
\hline Control & 29 & 108.72 & 14.56 & & & & \\
\hline
\end{tabular}

A significant difference was observed between the control and experimental groups in terms of students' community of inquiry perceptions $(t(57)=2.419 ; p<.05)$ in favor of the experimental group. The eta square value was calculated as .093. This value implies that CSLE has a medium level effect on students' community of inquiry perceptions. In order to identify the effect of CSLE on social, cognitive, and teaching presence, an independent samples t-test was performed for each factor. Table 5 shows the results.

Table 5

Independent samples t-test results for social, cognitive, and teaching presence scores

\begin{tabular}{|c|c|c|c|c|c|c|c|c|}
\hline $\begin{array}{l}\text { Dependent } \\
\text { Variable }\end{array}$ & Groups & $N$ & Mean & $S D$ & $d f$ & $t$ & $p$ & $\eta 2$ \\
\hline \multirow{2}{*}{$\begin{array}{l}\text { Social } \\
\text { Presence }\end{array}$} & Experimental & 30 & 26.90 & 6.17 & \multirow[t]{2}{*}{57} & \multirow[t]{2}{*}{.209} & \multirow[t]{2}{*}{.835} & \multirow[t]{2}{*}{-} \\
\hline & Control & 29 & 26.59 & 5.29 & & & & \\
\hline \multirow{2}{*}{$\begin{array}{l}\text { Cognitive } \\
\text { Presence }\end{array}$} & Experimental & 30 & 42.77 & 3.89 & \multirow[t]{2}{*}{57} & \multirow[t]{2}{*}{4.210} & \multirow[t]{2}{*}{.000} & \multirow[t]{2}{*}{.237} \\
\hline & Control & 29 & 37.31 & 5.89 & & & & \\
\hline \multirow{2}{*}{$\begin{array}{l}\text { Teaching } \\
\text { Presence }\end{array}$} & Experimental & 30 & 47.37 & 3.90 & \multirow[t]{2}{*}{57} & \multirow[t]{2}{*}{2.168} & \multirow[t]{2}{*}{.034} & \multirow[t]{2}{*}{.076} \\
\hline & Control & 29 & 44.83 & 5.04 & & & & \\
\hline
\end{tabular}

There is a significant difference between the control and experimental groups in terms of cognitive presence $(t(57)=4.210 ; p<.05)$ and teaching presence $(t(57)=2.168 ; p<.05)$ scores in favor of the experimental group. The eta square value was calculated as .237 for the cognitive presence scores and .076 for the teaching presence scores. In other words, while CSLE has a large effect on students' cognitive presence scores, this effect was at a medium level for the teaching presence scores.

\subsection{Interaction Level}

The second research question concerned the groups' interaction levels. In order to determine whether there is a significant difference between groups' interaction level scores, an independent samples t-test was performed. The analysis results are given in Table 6. 
Table 6

Independent samples t-test results for the groups' interaction level scores

\begin{tabular}{|c|c|c|c|c|c|c|c|}
\hline Groups & $N$ & Mean & $S D$ & $d f$ & $t$ & $p$ & $\eta 2$ \\
\hline Experimental & 30 & 61.03 & 4.84 & 57 & 3.297 & .002 & .160 \\
\hline Control & 29 & 56.69 & 5.27 & & & & \\
\hline
\end{tabular}

The results reveal that there is significant difference between the groups in terms of their interaction level scores $(\mathrm{t}(57)=3.297 ; \mathrm{p}<.05)$ in favor of the experimental group. The scores were obtained through the online course interaction level determination scale and the eta square value was calculated as .160, which refers to a strong effect of CSLE on the students' interaction level.

\section{Discussion and Conclusion}

The aim of this study is to examine collaborative synchronous learning environments in terms of community of inquiry model and interaction. Within this context, the control and experimental groups' community of inquiry perceptions were investigated. The results revealed that the experimental group had significantly higher perception scores compared to the control group. This finding implies that compared with teacher-centered instruction in online synchronous settings, CSLE provides a more effective learning experience for students. A collaborative learning approach encourages learning through socio-cognitive communication and increases individual learning performance (Kwon et al., 2014; Medina \& Suthers, 2008; Oakley et al., 2004; Tomcho \& Foels, 2012). This study reveals a positive effect of collaborative learning in online environments. In another study, $\mathrm{Ku}$ and his colleagues (2013) found that students gain more knowledge in CSLE compared to individual learning. The reason might be that collaborative learning activities enable students to think about ideas that they cannot when they are alone (Chi \& Wylie, 2014). This may also reflect the widespread use of collaborative learning in online learning environments, in addition to real classrooms (Fischer et al., 2007; Liu \& Tsai, 2008; Özyurt \& Özyurt, 2013).

Among the sub-dimensions of the community of inquiry model, a significant difference was observed in students' cognitive and teaching presence scores in favor of the experimental group. However, no significant difference was observed for the social presence scores of the groups. Considering the results of the studies focus on the association between social presence and teaching and cognitive presence (Garrison et al., 2010; Kozan \& Caskurlu, 2018), this result is surprising. A possible explanation is that a number of students did not attend the online courses with their cameras turned on due to technical problems, which might have negatively affected their social presence perceptions. Although Borup and his colleagues (2012) state that video communication cannot replace emotional communication in real classrooms, it is still critical for teachers and students to attend the online lessons with cameras on in terms of social presence (Pinks et al., 2014). In addition, Garrison et al. (1999) postulate that social presence, that is strengthened by a sense of belonging, which develops as a result of students' knowing each other in person and showing commitment in their social relations, is critical for a group to complete a task as a group. Since the participants in the study were freshmen, they did not have a chance to meet their classmates in person, only communicating with each other through online courses, knew little about each other, and did not have any sharing except for course activities. These might have negatively affected their social presence perceptions. Future research must consider factors affecting students' social presence perception. In addition, empirical studies are needed to examine how to increase students' social presence through those factors in the context of CSLE.

Interaction is considered as a critical limitation for online learning environments (Anderson 2003). This study also examines the effects of CSLE on students' interaction levels. The significant result is in favor of the experimental group. A number of studies report weak interaction among students in environments in which collaborative learning was rarely employed, which resulted in negatively affected learning achievement (Garrison et al., 2010; Onrubia \& Engel, 2012). Interaction increases students' motivation and their potential to achieve learning outcomes (Pérez-Mateo \& 
Guitert, 2012). Considering its direct effect on students' achievement (Cheng \& Chau, 2016; Ji et al., 2016) and the need for more research to examine how to increase interaction in online settings (Owusu-Agyeman \& Larbi-Siaw, 2018), interaction is also a critical factor in emergency remote education. The reason for this is that development of emergency remote education has the power to influence many teachers and students all over the world. In particular, learner-learner interaction that is facilitated through technological devices may increase the effectiveness of collaborative learning (Blasco-Arcas et al., 2013). Breakout rooms play an important role in increasing interaction in group work. The findings of the current study and other studies reveal that, in order to increase interaction in online learning environments, the collaborative learning approach should be integrated in teaching. Therefore, there is a strong need for empirical studies considering various variables, including students' motivation and perceived learning, to examine the effectiveness of online learning environments. Besides, the enrichment of the curricula to be prepared for the distance education with activities which are suitable for cooperation can produce effective results in the context of interaction.

\subsection{Limitations and Future Directions}

This study examines CSLE in terms of the community of inquiry model and interaction and reported critical findings. However, a number of limitations exist in the study. The first limitation concerns the sample of the study. The participants consisted of fifty-nine university freshmen students. This study must be replicated with the participation of students who are in their second year or higher in order to determine more about their social presence perceptions. This study was also limited to the Information Technologies course and the abovementioned objectives. The course is generally practice-based; therefore, future studies must consider adapting CSLE into different courses to determine its effectiveness. In the study, two scales, the Community of Inquiry Scale and the Online Course Interaction Level Determination Scale, were not administered as pretests before the implementation, since their content was related to activities planned to be conducted during the implementation process. This might be considered as another limitation in determining any similarity between the control and experimental groups. Although certain other variables related to demographic information regarding the participants were considered in this determination, future research must consider using other questionnaires that can be used as both pre-test and post-test.

\section{References}

Adarkwah, M. A. (2021). "I'm not against online teaching, but what about us?": ICT in Ghana post Covid19. Education and Information Technologies, 26, 1-21. https:// doi.org/10.1007/s10639-020-10331-z

Aguilera-Hermida, A. P. (2020). College students' use and acceptance of emergency online learning due to Covid-19. International Journal of Educational Research Open,1, 1-18. https://doi.org/10.1016/j.ijedro.2020.100011

Akyol, Z., \& Garrison, D. R. (2011). Understanding cognitive presence in an online and blended community of inquiry: Assessing outcomes and processes for deep approaches to learning. British Journal of Educational Technology, 42(2), 233-250. https://doi.org/10.1111/j.1467-8535.2009.01029.x

Al Lily, A. E., Ismail, A. F., Abunasser, F. M., \& Alqahtani, R. H. A. (2020). Distance education as a response to pandemics: Coronavirus and Arab culture. Technology in Society, 63, 1-11. https://doi.org/10.1016/j.techsoc.2020.101317

Al Mamun, M. A., Lawrie, G., \& Wright, T. (2020). Instructional design of scaffolded online learning modules for self-directed and inquiry-based learning environments. Computers $\&$ Education, 144, 1-17. https://doi.org/10.1016/j.compedu.2019.103695

Alfonseca, E., Carro, R. M., Martín, E., Ortigosa, A., \& Paredes, P. (2006). The impact of learning styles on student grouping for collaborative learning: a case study. User Modeling and User-Adapted Interaction, 16(34), 377-401. https:// doi.org/10.1007/s11257-006-9012-7 
Almaiah, M. A., Al-Khasawneh, A., \& Althunibat, A. (2020). Exploring the critical challenges and factors influencing the E-learning system usage during COVID-19 pandemic. Education and Information Technologies, 25, 5261-5280. https://doi.org/10.1007/s10639-020-10120-8

Al-Musharraf, A., \& Alkhattabi, M. (2016). An educational data mining approach to explore the effect of using interactive supporting features in an LMS for overall performance within an online learning environment. International Journal of Computer Science and Network Security, 16(3), 1-2.

Anderson, T. (2003). Getting the mix right again: An updated and theoretical rationale for interaction. International Review of Research in Open and Distance Learning, 4(2), 9-14. https://doi.org/10.19173/irrodl.v4i2.149

Anderson, T. (Ed.). (2008). The theory and practice of online learning. Athabasca University Press.

Anderson, T., \& Garrison, D. R. (1998). Learning in a networked world: New roles and responsibilities. In C. Gibson (Ed.), Distance learners in higher education (pp. 97-112). Atwood Publishing.

Arbaugh, J. B., Cleveland-Innes, M., Diaz, S. R., Garrison, D. R., Ice, P., Richardson, J. C., \& Swan, K. P. (2008). Developing a community of inquiry instrument: Testing a measure of the Community of Inquiry framework using a multi-institutional sample. The Internet and Higher Education, 11(3-4), 133-136. https://doi.org/10.1016/j.iheduc.2008.06.003

Arenas, E. (2015). Affordances of learning technologies in higher education multicultural environments. Electronic Journal of E-Learning, 13(4), 217-227. https://academicpublishing.org/index.php/ejel/article/view/1729/1692

Bernard, R. M., Abrami, P. C., Borokhovski, E., Wade, C. A., Tamim, R. M., Surkes, M. A., \& Bethel, E. C. (2009). A meta-analysis of three types of interaction treatments in distance education. Review of Educational Research, 79(3), 1243-1289. https://doi.org/10.3102/0034654309333844

Blasco-Arcas, L., Buil, I., Hernández-Ortega, B., \& Sese, F. J. (2013). Using clickers in class: The role of interactivity, active collaborative learning and engagement in learning performance. Computers $\mathcal{E}$ Education, 62, 102-110. https://doi.org/10.1016/j.compedu.2012.10.019

Borup, J., West, R. E., \& Graham, C. R. (2012). Improving online social presence through asynchronous video. The Internet and Higher Education, 15(3), 195-203. https://doi.org/10.1016/j.iheduc.2011.11.001

Bower, M. (2019). Technology-mediated learning theory. British Journal of Educational Technology, 50(3), 10351048. https://doi.org/10.1111/bjet.12771

Burke, J., \& Dempsey, M. (2020). COVID-19 Practice in primary schools in Ireland report. National University of Ireland Maynooth, Ireland. https://www.ippn.ie/images/PDFs/Covid19_Practice_in_Primary_Schools_Report.pdf

Butler-Henderson, K., \& Crawford, J. (2020). A systematic review of online examinations: A pedagogical innovation for scalable authentication and integrity. Computers $\mathcal{E}$ Education, 159, 104024. https://doi.org/10.1016/j.compedu.2020.104024

Chan, T., Chen, C. M., Wu, Y. L., Jong, B. S., Hsia, Y. T., \& Lin, T. W. (2010). Applying the genetic encoded conceptual graph to grouping learning. Expert Systems with Applications, 37(6), 4103-4118. https:// doi.org/10.1016/j.eswa.2009.11.014

Chen, C. M., \& Kuo, C. H. (2019). An optimized group formation scheme to promote collaborative problembased learning. Computers $\mathcal{E}$ Education, 133, 94-115. https:// doi.org/10.1016/j.compedu.2019.01.011

Cheng, G., \& Chau, J. (2016). Exploring the relationships between learning styles, online participation, learning achievement and course satisfaction: An empirical study of a blended learning course. British Journal of Educational Technology, 47(2), 257-278. https://doi.org/10.1111/bjet.12243

Chi, M. T. H., \& Wylie, R. (2014). The ICAP framework: Linking cognitive engagement to active learning outcomes. Educational Psychologist, 49(4), 219-243. https:// doi.org/10.1080/00461520.2014.965823

Cohen, J. (1992). A power primer. Psychological Bulletin, 112(1), 155.

Coşkun, H. (2009). The interaction anxiousness scale: A study for validity and reliability. Turkish Psychological Articles, 12(23), 41-49.

Deshmukh, S. R. (2020). Social Realities of Higher Education in the Age of Uncertainties. Smart Moves Journal IJELLH, 8(4), 279-289. https:// doi.org/10.24113/ijellh.v8i4.10547

Eom, S. B., \& Ashill, N. (2016). The determinants of students' perceived learning outcomes and satisfaction in university online education: An update. Decision Sciences Journal of Innovative Education, 14(2), 185-215. https://doi.org/10.1111/dsji.12097

Fischer, G., Rohde, M., \& Wulf, V. (2007). Community-based learning: The core competency of residential, research-based universities. International Journal of Computer-Supported Collaborative Learning, 2(1), 9-40. https://doi.org/10.1007/s11412-007-9009-1 
Garrison, D. R. (2011). E-learning in the 21st century: A framework for research and practice. Taylor \& Francis.

Garrison, D. R., Anderson, T., \& Archer, W. (1999). Critical inquiry in a text-based environment: Computer conferencing in higher education. The Internet and Higher Education,2(2-3), 87-105. https://doi.org/10.1016/S1096-7516(00)00016-6

Garrison, D. R., Anderson, T., \& Archer, W. (2001). Critical thinking, cognitive presence, and computer conferencing in distance education. American Journal of Distance Education, 15(1), 7-23. https://doi.org/10.1080/08923640109527071

Garrison, D. R., Cleveland-Innes, M., \& Fung, T. S. (2010). Exploring causal relationships among teaching, cognitive and social presence: Student perceptions of the community of inquiry framework. The Internet and Higher Education, 13(1-2), 31-36. https://doi.org/10.1016/j.iheduc.2009.10.002

Gonzalez, T., De La Rubia, M. A., Hincz, K. P., Comas-Lopez, M., Subirats, L., Fort, S., \& Sacha, G. M. (2020). Influence of COVID-19 confinement on students' performance in higher education. PloS one, 15(10), 1-23. https://doi.org/10.1371/journal.pone.0239490

Grau, V., \& Whitebread, D. (2012). Self and social regulation of learning during collaborative activities in the classroom: The interplay of individual and group cognition. Learning and Instruction, 22(6), 401-412. https://doi.org/10.1016/j.learninstruc.2012.03.003

Hawkins, A., Graham, C. R., Sudweeks, R. R., \& Barbour, M. K. (2013). Academic performance, course completion rates, and student perception of the quality and frequency of interaction in a virtual high school. Distance Education, 34(1), 64-83. https://doi.org/10.1080/01587919.2013.770430

Heo, J., \& Han, I. (2003). Performance measure of information systems (IS) in evolving computing environments: an empirical investigation. Information $\mathcal{E}$ Management, 40(4), 243-256. https://doi.org/10.1016/S0378-7206(02)00007-1

Hillman, D. C. A., Willis, D. J., \& Gunawardena, C. N. (1994). Learner-interface interaction in distance education: An extension of contemporary models and strategies for practitioners. American Journal of Distance Education, 8, 30-42. https:// doi.org/10.1080/08923649409526853

Hilton, S., \& Phillips, F. (2010). Instructor-assigned and student-selected groups: A view from inside. Issues in Accounting Education, 25(1), 15-33. https://doi.org/10.2308/iace.2010.25.1.15

Huxham, M., \& Land, R. (2000). Assigning students in group work projects. Can we do better than random? Innovations in Education and Training International, 37(1), 17-22. https://doi.org/10.1080/135580000362043

Ishak, T., Kurniawan, R., Zainuddin, Z., \& Keumala, C. M. (2020). The role of pre-class asynchronous online video lectures in flipped-class instruction: Identifying students' perceived need satisfaction. Journal of Pedagogical Research, 4(1), 1-11. https://doi.org/10.33902/jpr.v4i1.145

Järvelä, S., Järvenoja, H., \& Veermans, M. (2008). Understanding the dynamics of motivation in socially shared learning. International Journal of Educational Research, 47(2), 122-135. https://doi.org/10.1016/j.ijer.2007.11.012

Järvelä, S., \& Järvenoja, H. (2011). Socially constructed self-regulated learning and motivation regulation in collaborative learning groups. Teachers College Record, 113(2), 350-374.

Ji, H., Park, K., Jo, J., \& Lim, H. (2016). Mining students activities from a computer supported collaborative learning system based on peer to peer network. Peer-to-Peer Networking and Applications, 9(3), 465-476. https:// doi.org/10.1007/s12083-015-0397-0

Joo, Y. J., Lim, K. Y., \& Kim, E. K. (2011). Online university students' satisfaction and persistence: Examining perceived level of presence, usefulness and ease of use as predictors in a structural model. Computers $\mathcal{E}$ Education, 57(2), 1654-1664. https://doi.org/10.1016/j.compedu.2011.02.008

Kaplan-Rakowski, R. (2020). Addressing students' emotional needs during the COVID-19 pandemic: a perspective on text versus video feedback in online environments. Educational Technology Research and Development, 69, 133-136. https:// doi.org/10.1007/s11423-020-09897-9

Karaman, G. E. (2015). Development of an online course interaction level determination scale and design of automated estimation system [Unpublished doctoral dissertation]. Atatürk University, Erzurum.

Kopp, B., Matteucci, M. C., \& Tomasetto, C. (2012). E-tutorial support for collaborative online learning: An explorative study on experienced and inexperienced e-tutors. Computers $\mathcal{E}$ Education, 58(1), 12-20. https://doi.org/10.1016/j.compedu.2011.08.019

Korkut Owen, F. \& Bugay, A. (2014). İletişim becerileri ölçeği'nin geliştirilmesi: Geçerlik ve güvenirlik çalışması. Mersin Üniversitesi Eğitim Fakültesi Dergisi, 10(2), 51-64.

Kozan, K., \& Caskurlu, S. (2018). On the Nth presence for the Community of Inquiry framework. Computers \& Education, 122, 104-118. https://doi.org/10.1016/j.compedu.2018.03.010 
Kozan, K., \& Richardson, J. C. (2014). Interrelationships between and among social, teaching, and cognitive presence. The Internet and Higher Education, 21, 68-73. https:/ / doi.org/10.1016/j.iheduc.2013.10.007

Ku, H. Y., Tseng, H. W., \& Akarasriworn, C. (2013). Collaboration factors, teamwork satisfaction, and student attitudes toward online collaborative learning. Computers in Human Behavior, 29(3), 922-929. https://doi.org/10.1016/j.chb.2012.12.019

Kwon, K., Liu, Y. H., \& Johnson, L. P. (2014). Group regulation and social-emotional interactions observed in computer supported collaborative learning: Comparison between good vs. poor collaborators. Computers $\mathcal{E}$ Education, 78, 185-200. https://doi.org/10.1016/j.compedu.2014.06.004

Lee, J. K., \& Lee, W. K. (2008). The relationship of e-Learner's self-regulatory efficacy and perception of eLearning environmental quality. Computers in Human Behavior, 24(1), 32-47. https://doi.org/10.1016/j.chb.2006.12.001

Lee, R., Hoe Looi, K., Faulkner, M., \& Neale, L. (2020). The moderating influence of environment factors in an extended community of inquiry model of e-learning. Asia Pacific Journal of Education, 41(1), 1-15. https:// doi.org/10.1080/02188791.2020.1758032

Lee, S. J., Srinivasan, S., Trail, T., Lewis, D., \& Lopez, S. (2011). Examining the relationship among student perception of support, course satisfaction, and learning outcomes in online learning. The Internet and Higher Education, 14(3), 158-163. https://doi.org/10.1016/j.iheduc.2011.04.001

Liu, C. C., \& Tsai, C. C. (2008). An analysis of peer interaction patterns as discoursed by on-line small group $\begin{array}{llll}\text { problem-solving } & \text { activity. Computers } & \mathcal{E} & \text { Education, 50(3), }\end{array}$ https://doi.org/10.1016/j.compedu.2006.07.002

Lou, Y., Bernard, R. M., \& Abrami, P. C. (2006). Media and pedagogy in undergraduate distance education: A theory-based meta-analysis of empirical literature. Educational Technology Research and Development, 5(2), 141-176. https:// doi.org/10.1007/s11423-006-8252-x

Maddrell, J. A., Morrison, G. R., \& Watson, G. S. (2017). Presence and learning in a community of inquiry. Distance Education, 38(2), 245-258. https://doi.org/10.1080/01587919.2017.1322062

McMillan, J. H., \& Schumacher, S. (2010). Research in Education: Evidence-Based Inquiry, MyEducationLab Series. Pearson.

Medina, R. \& Suthers, D. (2008). Bringing Representational Practice From Log to Light. In Kanselaar, G., Jonker, V., Kirschner, P. A., \& Prins, F. J. (Eds.), International Perspectives in the Learning Sciences: Cre8ing a learning world. Proceedings of the Eighth International Conference for the Learning Sciences - ICLS 2008, (Vol 2. pp. 59-66). International Society of the Learning Sciences. https://doi.dx.org/10.22318/icls2008.2.59

Mills, J., Yates, K., Harrison, H., Woods, C., Chamberlain-Salaun, J., Trueman, S., \& Hitchins, M. (2016). Using a community of inquiry framework to teach a nursing and midwifery research subject: An evaluative study. Nurse Education Today, 43, 34-39. https://doi.org/10.1016/j.nedt.2016.04.016

Mishra, L., Gupta, T., \& Shree, A. (2020). Online teaching-learning in higher education during lockdown period of COVID-19 pandemic. International Journal of Educational Research Open, 1, 1-8. https://doi.org/10.1016/j.ijedro.2020.100012

Moore, M. G. (1989). Editorial: Three types of interaction. American Journal of Distance Education, 3, 1-7. doi:10.1080/08923648909526659

Moreno, J., Ovalle, D. A., \& Vicari, R. M. (2012). A genetic algorithm approach for group formation in collaborative learning considering multiple student characteristics. Computers $\mathcal{E}$ Education, 58(1), 560-569. https://doi.org/10.1016/j.compedu.2011.09.011

Oakley, B., Felder, R. M., Brent, R., \& Elhajj, I. (2004). Turning student groups into effective teams. Journal of Student Centered Learning, 2(1), 9-34.

Oliveira, I., Tinoca, L., \& Pereira, A. (2011). Online group work patterns: How to promote a successful collaboration. Computers \& Education, 57(1), 1348-1357. https://doi.org/10.1016/j.compedu.2011.01.017

Onrubia, J., \& Engel, A. (2012). The role of teacher assistance on the effects of a macro-script in collaborative writing tasks. International Journal of Computer-Supported Collaborative Learning, 7(1), 161-186. https:// doi.org/10.1007/s11412-011-9125-9

Ornellas, A., \& Muñoz Carril, P. C. (2014). A methodological approach to support collaborative media creation in an e-learning higher education context. Open Learning: The Journal of Open, Distance and eLearning, 29(1), 59-71. https:// doi.org/10.1080/02680513.2014.906916

Owusu-Agyeman, Y., \& Larbi-Siaw, O. (2018). Exploring the factors that enhance student-content interaction in a technology-mediated learning environment. Cogent Education, 5(1), 1456780. 10.1080/2331186X.2018.1456780 
Ozkan, S., \& Koseler, R. (2009). Multi-dimensional students' evaluation of e-learning systems in the higher education context: An empirical investigation. Computers \& Education, 53(4), 1285-1296.

Öztürk, E. (2012). An adaptation of the community of inquiry index: The study of validity and reliability. Elementary Education Online, 11(2), 408-422. https://doi.org/10.1016/j.compedu.2009.06.011

Özyurt, Ö., \& Özyurt, H. (2013). An examination of computer engineering students' perceptions about asynchronous discussion forums. EURASIA Journal of Mathematics, Science and Technology Education, 9(4), 371-378. https://doi.org/10.12973/eurasia.2013.941a

Pal, D., \& Patra, S. (2020). University Students' Perception of Video-Based Learning in Times of COVID-19: A TAM/TTF Perspective. International Journal of Human-Computer Interaction, 1-19. https:// doi.org/10.1080/10447318.2020.1848164

Pallant, J. (2016). SPSS survival manual a step by step guide to data analysis using SPSS program (6th ed.). McGraw-Hill Education.

Paswan, A. K., \& Young, J. A. (2002). Student evaluation of instructor: A nomological investigation using structural equation modeling. Journal of Marketing Education, 24(3), 193-202. https:// doi.org/10.1177/0273475302238042

Pérez-Mateo, M., \& Guitert, M. (2012). Which social elements are visible in virtual groups? Addressing the categorization of social expressions. Computers \& Education, 58(4), 1234-1246. https://doi.org/10.1016/j.compedu.2011.12.014

Petronzi, R., \& Petronzi, D. (2020). The Online and Campus (OaC) model as a sustainable blended approach to teaching and learning in higher education: A response to COVID-19. Journal of Pedagogical Research, 4(4), 498-507. https://doi.org/10.33902/JPR.2020064475

Pinsk, R., Curran, M.J., Poirier, R., \& Coulson, G. (2014). Student perceptions of the use of student-generated online discussions as a mechanism to establish social presence for non-traditional students: A case study. Issues in Information Systems, 15(1), 267-276. https://iacis.org/iis/2014/49_iis_2014_267-276.pdf

Prince, M. (2004). Does active learning work? A review of the research. Journal of Engineering Education, 93(3), 223-231.

Redmond, P. \& Lock, J. V. (2006). A flexible framework for online collaborative learning. The Internet and Higher Education, 9(4), 1-10. https:/ / doi.org/10.1016/j.iheduc.2006.08.003

Scheuerell, S. (2010). Virtual Warrensburg: Using cooperative learning and the internet in the social studies classroom. The Social Studies, 101(5), 194-199. https:// doi.org/10.1080/00377990903493861

Shire, S. Y., Worthman, L. B., Shih, W., \& Kasari, C. (2020). Comparison of face-to-face and remote support for interventionists learning to deliver JASPER intervention with children who have autism. Journal of Behavioral Education, 29, 317-338. https://doi.org/10.1007/s10864-020-09376-4

Sun, L., Tang, Y., \& Zuo, W. (2020). Coronavirus pushes education online. Nature Materials, 19(6), 687-687. https://doi.org/10.1038/s41563-020-0678-8

Szeto, E. (2015). Community of Inquiry as an instructional approach: What effects of teaching, social and cognitive presences are there in blended synchronous learning and teaching? Computers $\mathcal{E}$ Education, 81, 191-201. https:// doi.org/10.1016/j.compedu.2014.10.015

Tareef, A. B. (2014). The effects of computer-assisted learning on the achievement and problem solving skills of the educational statistics students. European Scientific Journal, 10(28), 271-279.

Tomcho, T. J., \& Foels, R. (2012). Meta-analysis of group learning activities: Empirically based teaching recommendations. Teaching of Psychology, 39(3), 159-169. https:// doi.org/10.1177/0098628312450414

Turgut, Y., \& Karal, H. (2015). Factors affecting interaction in a distance education via video conferencing. Journal of Instructional Technologies \& Teacher Education, 4(1), 1-12.

UNESCO Report (2020). UNESCO Report, 'National learning platforms and tools'. https://en.unesco.org/covid19/educationresponse/nationalresponses.

Yang, X., Zhang, M., Kong, L., Wang, Q., \& Hong, J. C. (2020). The effects of scientific self-efficacy and cognitive anxiety on science engagement with the "question-observation-doing-explanation" model during school disruption in COVID-19 pandemic. Journal of Science Education and Technology, 1-14. https://doi.org/10.1007/s10956-020-09877-x

Zhang, J. H., Zhang, Y. X., Zou, Q., \& Huang, S. (2018). What learning analytics tells us: Group behavior analysis and individ-ual learning diagnosis based on long-term and large-scale data. Journal of Educational Technology \& Society, 21(2), 245-258. 